\title{
PARTISIPASI MASYARAKAT DALAM PEMBUATAN PERATURAN DAERAH (PERDA)
}

COMMUNITY PARTICIPATION IN THE MAKING OF LOCAL REGULATIONS

Amir Muhiddin

Program Studi Ilmu Pemerintahan Fakultas Ilmu Sosial Dan Ilmu Politik Universitas Pancasakti Makassar Jl. Andi Mangerangi No 73, Makassar 90223

\section{ABSTRACT}

Community participation in the making of regulations is one form of democratic government, and therefore the community should be given the widest possible space for he highest authority in the country adopts democracy. People are expected to not only enjoy the development alone, but is also expected to set about to the end of development where it is directed, therefore people should be included from the rulemaking will be guiding and controlling up to implementation and evaluation as well. Community participation in the development process means that people also take part responsible, in the future if an error occurs or deviations in development.

Keywords : Participation, Community and Legal Drafting

\section{ABSTRAK}

Partisipasi masyarakat dalam pembuatan perda merupakan salah satu wujud pemerintahan yang demokratis, oleh sebab itu masyarkat perlu diberi ruang yang seluas-luasnya karena dialah pemegang kekuasaan tertinggi dalam negara yang menganut paham demokrasi. Rakyat diharapkan bukan sekedar menikmati pembangunan semata, akan tetapi juga diharapkan menata hendak kemana akhirnya pembangunan itu diarahkan, oleh sebab itu rakyat hendaknya diikut sertakan mulai dari pembuatan peraturan yang akan menjadi penuntun dan pengendali sampai kepada pelaksanaan dan sekaligus evaluasi. Partisipasi masyarakat dalam proses pembangunan berarti masyarakat juga ikut serta bertanggung jawab, apabila dikemudian hari terjadi kesalahan atau penyimpangan dalam pembangunan.

Kata Kunci : Partisipasi, Masyarakat, dan Pembuatan Perda 


\section{A. PENDAHULUAN}

Pasca diundangkannya UU Pemerintahan Daerah, ribuan peraturan daerah lahir, baik Perda provinsi maupun perda kabupaten/ kota. Perubahan Undang-Undang Pemerintahan Daerah menjadi Undang-Undang No.32 Tahun 2004 tentang Pemerintahan Daerah juga memberikan perubahan signifikan terhadap pembentukan Perda. Hal ini disebabkan, karena Undang-Undang ini diatur secara rinci apa yang menjadi kewenangan pemerin-tahan daerah. Pengaturan ini bahkan membagi pula kewenangan pemerintahan di tingkat provinsi dan kabupaten/kota. Urusan yang menjadi kewenangan daerah diatur lebih lanjut dengan Peraturan Pemerintah No. 38 Tahun 2007 tentang Pembagian Urusan Pemerintahan antara Pemerintah, Pemerintahan Daerah Provinsi, dan Pemerintahan Daerah Kabupaten/Kota.

Adanya wewenang untuk membuat Perda sendiri merupakan harapan baru karena pemerintah di tingkat lokal dapat memberdayakan daerah dalam mengatasi persoalanpersoalan riil yang dihadapi masyarakat seperti kemiskinan, pengangguran, perdagangan perempuan-anak, pengabaian hakhak minoritas, dan sebagainya. Harapan ini muncul dikaitkan dengan sejumlah asumsi diantaranya adalah daerah lebih mengetahui konteks lokal baik sosial maupun budaya dan juga kebutuhan dasar masyarakatnya. Dengan asumsi ini, kehadiran perda diharapkan dapat memberikan ruang perlindungan yang lebih tepat dan mudah diakses oleh masyarakat di daerah tersebut.

Kewenangan untuk menyusun Peraturan Daerah setelah otonomi daerah membuat jumlah Peraturan Daerah sampai dengan pertengahan 2002 melonjak tinggi, yakni mencapai 6000-an yang diterbitkan oleh 368 kabupaten/kota di Indonesia. Dari jumlah Peraturan Daerah tersebut, 761 diantaranya dibatalkan dan masih ada 200 Peraturan Daerah yang masih dalam proses review di Kementrian Dalam Negeri. Peraturan Daerah yang dibatalkan tersebut pada umumnya Peraturan Daerah yang mengatur pajak daerah dan retribusi daerah karena dinilai berpotensi mendistorsi aktifitas perekonomian. Selain itu, terdapat berbagai Peraturan Daerah yang kontroversi dan bermasalah pada tingkat implementasinya di tengah masyarakat terkait dengan Hak Asasi Manusia, diskriminasi, kesetaraan jender, pencemaran lingkungan dan sebagainya.

Banyaknya Peraturan Daerah yang dibatalkan dan penolakan dari masyarakat menimbulkan pertanyaan-pertanyaan terhadap proses pembentukan Peraturan Daerah. Bagaimana proses tersebut berjalan? Apa kekurangan dari proses yang ada saat ini? Dinamika politik seperti apa yang muncul selama proses pembentukan tersebut dilakukan sehingga berakhir dengan pembentukan Peraturan Daerah yang kontroversial dan bermasalah dalam implementasinya sampai dengan terindikasi terjadi pelanggaran hak asasi manusia. Situasi ini mengakibatkan meningkatnya tuntutan dari banyak pihak untuk mengintegrasikan hak asasi manusia ke dalam Peraturan Daerah. Oleh karenanya, peran pemerintah daerah dalam memenuhi, menghormati dan melin-dungi hak asasi manusia sangatlah penting.

Oleh karena itu, tugas praktis untuk melindungi dan memajukan hak asasi manusia adalah terutama tugas nasional dan setiap negara harus bertanggungjawab atasnya. Pada tingkat nasional, hak dapat dilindungi dengan baik melalui peraturan yang cukup, badan peradilan yang mandiri, dan pelaksanaan perlindungan dan pemulihan individu, serta pembentukan institusi yang demokratis. Selain itu, pendidikan dan kampanye informasi yang paling efektif harus dirancang dan dilaksanakan pada tingkat nasional dan lokal, dengan mempertimbangkan konteks budaya dan tradisi lokal. Ketika negara-negara meratifikasi suatu instrumen partisiapsi, mereka memasukkan ketentuanketentuan instrumen partisipasi itu ke dalam peraturan domestiknya secara langsung atau menggunakan cara-cara lain sesuai dengan kewajiban yang terdapat di dalam instrumen partisipasi masyarakat tersebut.

Partisipasi masyarakat merupakan bagian tak terpisahkan dari upaya untuk melaksanakan pemerintahan yang demokratis. Partisipasi 
dimulai dari perencanaan sampai kepada pelaksanaan dan evaluasi. Upaya ini dilakukan agar masyarakat dilibatkan dalam pembangunan, bukan sekedar menikmati semata, melainkan ikut serta merancang, dan menata hendak kemana akhirnya pembangunan itu diarahkan.

Salah satu bentuk keikutsertaan masyarakat dalam merancang pembangunan adalah dilibatkannya mereka dalam pembuatan peraturan, termasuk peraturan daerah yang disingkat dengan Perda. Dengan demikian segala aktifitas pemerintahan dan pembangunan, masyarakat memperoleh kesempatan mengikuti proses, mulai dari pembuatan peraturan yang akan menjadi penuntun dan pengendali sampai kepada pelaksanaan dan sekaligus evaluasi. Itu berarti masyarakat juga ikut serta bertanggung jawab, apabila dikemudian hari terjadi kesalahan atau penyimpangan pembangunan.

Undang-Undang No. 10 tahun 2004 tentang Pembentukan Peraturan Perundang undangan, dalam pasal 53 secara jelas mengatur mengenai Partisipasi Masyarakat dalam Pembentukan Peraturan Perundangundangan termasuk Perda. Partisipasi masyarakat ini merupakan salah satu bentuk partisipasi politik masyarakat yang sangat penting dalam rangka menciptakan good governance.

Partisipasi masyarakat dalam UU No.10 tahun 2004 tentang Pembentukan Peraturan Perundang-Undangan diatur pada Bab X pasal 53 yang menyatakan bahwa masyarakat berhak memberikan masukan secara lisan atau tertulis dalam rangka penyiapan atau pembahasan rancangan undang-undang dan rancangan peraturan daerah. Penjelasan Pasal 53 itu menjelaskan bahwa hak masyarakat dalam ketentuan ini dilaksanakan sesuai dengan Peraturan Tata Tertib Dewan Perwakilan Rakyat/Dewan Perwakilan Rakyat Daerah. Senada dengan hal tersebut, dalam pasal 139 ayat (1) UU Nomor 32 Tahun 2004 Tentang Pemerintahan Daerah juga terdapat ketentuan bahwa masyarakat berhak memberikan masukan secara lisan atau tertulis dalam rangka penyiapan atau pembahasan rancangan Perda. Penjelasan Pasal 139 (1) tersebut menjelaskan bahwa hak masyarakat dalam ketentuan ini dilaksanakan sesuai dengan Peraturan Tata Tertib Dari bunyi pasal 53 UU Nomor 10 Tahun 2004 dan pasal 139 ayat (1) UU Nomor 32 Tahun 2004, serta Penjelasannya dapat diketahui bahwa: 1. Masyarakat berhak memberikan masukan dalam rangka penyiapan atau pembahasan rancangan Perda, 2 Masukan tersebut dapat dilakukan secara lisan atau tertulis. 3. Hak masyarakat tersebut dilaksanakan sesuai dengan Peraturan Tata Tertib DPRD.

Bagaimana hak-hak masyarakat tersebut dapat teraplikasi sangat ditentukan oleh kedua belah pihak, baik masyarakat, maupun pemerintah, meskipun demikian, pemerintah sekurang-kurangnya harus memberi ruang bagi masyarakat untuk berpartisipasi, misalnya membuat regulasi berkenan dengan bagaimana tehnis menyampaikan bentuk partisipasi tersebut, ini penting sebab selama ini yang dimaksud masyarakat tidak jelas, mulai dari personalnya sampai kepada jumlahnya.

Berdasarkan uraian di atas makan tulisan ini akan mengkaji bagaimana pentingnya partisipasi masyarakat, dan bagaimna aplikasinya di lapangan.

\section{B. ARTI DAN PENTINGNYA PARTISIPASI MASYARAKAT}

Pemerintahan Lokal mengacu pada status lingkup pengambilan keputusan yang telah didesentraslisasi dari Pemerintahan Pusat. Beetham (1996: 30) berpendapat bahwa pemerintahan lokal berpotensi lebih demokratis karena memiliki kapasitas untuk bertanggungjawab (responsiveness) dan representatif (representativeness). Misalnya, seorang wakil masyarakat terpilih mungkin lebih mudah dihubungi dan memiliki insentif yang besar untuk mengenali tuntutan lokalnya, dan mewakili bagian yang luas, khususnya perempuan dan kelompok etnik minoritas. Blair (2000: 21) juga berpendapat bahwa pemerintahan lokal potensial untuk jadi lebih demokratis karena, 'dengan membangun demokrasi popular dan akuntabilitas kepada pemerintahan lokal, pemerintah di tingkat 
lokal akan menjadi lebih responsif kepada tuntutan warganya, dan akan lebih efektif dalam penyelenggaraan pelayanan publiknya'. Menurut pandangan Blair, apakah suatu pemerintahan lokal demokratis atau tidak tergantung pada aspek akuntabilitas dari para wakil yang terpilih itu.

Meski demikian, padangan ini masih mempertimbangkan peran warga dan/atau warga negara pada pemerintahan lokal dalam logika demokrasi representatif. Warga negara berpartisipasi dan berperan dalam mencapai keseimbangan dan penanggulangan kemiskinan melalui pemilihan wakil yang lebih mewakili dan akuntabel untuk pemerintahan lokal. Bagaimanapun, ada pula pendekatan yang lain, yang menuntut peran warga yang lebih aktif, melalui partisipasi langsung dalam berbagai kegiatan publik. Pendekatan ini peduli (concerní) pada transformasi pengetahuan yang melampaui pengetahuan tentang ruang publik (public sphere) dan demokrasi representatif, dan menentang batasan-batasan antara ; public dan privat yang memungkinkan bentuk-bentuk yang lebih langsung dari keterkaitan demokratik (Gaventa \& Valderrama, 1999).

Peralihan bentuk demokrasi perwakilan menjadi bentuk-bentuk pemerintahan demokrasi langsung ini memerlukan perubahan dalam bagaimana mengkonseptualisasikan warga (citizen) dan kewargaan (citizenship). Formasi pemerintahan yang mengaitkan warga secara langsung menuntut sebuah pendekatan partisipasi warga yang memungkinkan warga, di manapun dan siapapun dia, menjadi pembuat dan penentu keputusan (Cornwall \& Gaventa, 2000), melalui perwakilan yang penuh dalam proses pemerintahan. Partisipasi warga menjadi sebuah konsep dan praktek yang melebihi pengetahuan-pengetahuan liberal tradisional tentang partisipasi politik yang terbatas pada kampanye dan pemilihan umum. Itu berarti partisipasi warga juga mencakup akses warga untuk mengidentifikasi prioritas lokal; merencanakan dan melaksanakan program; dengan mendudukkan warga sebagai aktor kunci pembuat kebijakan. Baik sebagai pelaksana maupun penerima manfaat dalam proses pemerintahan lokal. Satu hal penting dalam hal 'kelokalan' ini adalah, melalui proses desentralisasi, pemerintahan lokal dapat menyediakan kesempatan bagi Negara dan warganya untuk bersama-sama berpartisipasi dalam pemerintahan. Partisipasi warga dengan demikian dapat didefenisikan sebagai 'perluasan agenda masyarakat, di mana masyarakat dapat memobilisasi dan merumuskan tuntutannya (Cornwall \& Gaventa, 2001)

Sebagai klien atau penerima manfaat warga masyarakat dapat mempertanyakan kualitas atau biaya suatu pelayanan. Sebagai warga, warga masyarakat dapat menggunakan hak mereka untuk mengusulkan atau menolak kebijakan sosial yang akan mempengaruhi mereka. Mengamati sejarah partisipasi sejak tahun 1970-an hingga saat ini, Cornwall membedakan antara partisipasi yang dipaksakan (induced and invited participation) melalui kelompok pengguna, konsultasi, dan sejenisnya, dengan partisipasi warga, di mana warga 'masyarakat datang untuk membangun ruangnya sendiri dan melakukan perubahan menurut strateginya sendiri' (Cornwall, 2000: 77). Lebih jauh Cornwall mengatakan, rekonseptualisasi kewargaan akhirnya menempatkan warga sebagai 'pihak yang dapat bertindak' (as the exercise of agency), ketimbang sebagai sekumpulan hak dari identitas nasional. Pemaknaan kewargaan sebagai 'pihak yang dapat bertindak' ini menjadi dasar dari sebuah pendekatan yang lebih inklusif dengan sejumlah hak yang dikembangkan oleh warga itu sendiri.

Pemahaman baru partisipasi warga sebagai hak, dan sebagai ruang beraktifitas yang melampaui batasan-batasan antara Negara dan masyarakat sipil, juga menuntut pemahaman baru tentang apa yang dimaksud dengan pemerintahan (governance). Selayaknya warga dapat terkait dengan pemerintah lokal melalui wakil-wakilnya dan juga melalui sistem demokrasi partisipatif. Namun, aturan dan mekanisme untuk keterkaitan langsung ini perlu dimantapkan, 'agar dapat mengatur tata hubungan yang baru dari rasa saling percaya dan kerjasama untuk maju, khususnya jika sektor masyarakat yang secara historis 
aksesnya telah diabaikan dalam realita pembuatan kebijakan publik, ingin dilibatkan' (Fung \& Wright, 2001). Bagaimana caranya hubungan yang baru ini dimantapkan? Goetz and Gaventa (2001) berpendapat bahwa jika pemerintah mau memantapkan mekanisme partisipasi, upaya-upaya mereka akan jauh lebih efektif jika upaya-upaya itu sama dengan tuntutan warganegara. Jadi tantangannya sekarang adalah bagaimana membangun kapasitas yang sama pada kedua belah pihak. Itulah pemerintahan lokal yang partisipatif.

Dalam konteks tata pemerintahan, partisipasi warga seringkali dihubungkan dengan manajemen atau model pemerintahan. $M$. Gottdiener (1987) menghubungkan partisipasi dengan sistem tata pemerintahan (governance) yang berpusat rakyat. Tata pemerintahan yang berpusat rakyat merupakan pilihan yang harus ditempuh untuk menjamin keberlanjutan demokrasi, pembangunan, dan keadilan sosial. Pilihan ini mengandung konsekwensi harus semakin menguatnya partisipasi masyarakat di satu sisi, sementara di sisi yang lain pemerintah harus mengambil peran sebagai fasilitator dalam menegosiasikan berbagai kepentingan masyarakat yang berbeda atau saling bertentangan. Paritispasi berarti mendorong proses belajar bersama, komunikasi yang seimbang dalam membahas persoalan publik, menjadikan kesepakatan warga sebagai sumber utama dalam dalam pengambilan keputusan di tingkat politik formal, dan memberikan ruang yang cukup bagai rakyat untuk mengontrol keputusan publik agar dilaksanakan sesuai dengan tujuan yang telah ditetapkan. Sedangkan B. Guy Peters (1996), menghubungkan partisipasi dengan berkembangnya berbagai model pemerintahan. Menurut Peter, partisipasi yang luas dapat tumbuh dalam tata pemerintahan partisipatif (participatory state) yang lebih menekankan negosiasi dan keterlibatan dalam proses pengambilan kebijakan ketimbang hirarki dan teknokrasi.

Dalam tata pemerintahan yang berpusat rakyat atau tata pemerintahan partisipatif, kebijakan ditempatkan sebagai proses sosial politik tempat warga menegosiasikan alokasi barang dan anggaran publik. Kebijakan bukan persoalan teknis yang dapat diselesaikan secara teknokratis oleh kelompok orang yang dipercaya untuk merumuskan itu (biasanya politisi, birokrat, atau akademisi). Kebijakan merupakan ruang bagi teknisi dan anggota masyarakat untuk melakukan interaksi dan menggabungkan pengetahuan. Karena itu kebijakan harus melibatkan pihak yang luas, dan agar dapat terlaksana harus menjamin agar kepentingan berbagai pihak (stakeholders) sudah dikonfrontasi atau dinegosiasikan. Dalam perspektif ini partisipasi tidak dipandang sebagai cara melainkan tujuan itu sendiri.

Dalam konteks pemerintahan dan kebijakan publik, partisipasi telah mengundang perdebatan antara pendukung dan para kritisinya. Para pendukung partisipasi mengungkapkan keunggulan partisipasi yaitu: menjamin ketercapaian tujuan, membangun kapasitas lokal, meningkatkan cakupan pengambil kebijakan, target keuntungan yang lebih baik, menjamin keberlanjutan, dan menjamin suara kelompok marjinal terutama kelompok miskin dan perempuan terakomodasi. Sedangkan bagi kritisinya partisipasi dapat menyebabkan: membengkaknya biaya dan waktu untuk formulasi kebijakan, destabilisasi kekuatan politik, terlalu ideologis, dan menjatuhkan beban pada orang miskin.

Mengingat penerapan konsep partisipasi warga harus melibatkan struktur politik dan birokrasi pemerintahan, maka kerangka hukum merupakan syarat perlu (necessary condition). Hal ini disebabkan di satu sisi perangkat politik dan pemerintahan hanya mungkin bekerja berdasarkan pada aturan hukum, dan di sisi lain warga dapat masuk dalam proses pengambilan kebijakan publik bila ruang untuk partisipasi telah disediakan oleh perangkat hukum.

Partisipasi masyarakat bukan sekedar mengikut sertakan masyarakat dalam proses pelaksanaan pembangunan. lebih dari itu masyarakat juga harus mengetahui apa-apa saja yang pemerintah lakukan untuk menunjang kehidupan masyarakat, termasuk dalam kesejahteraannya. Partsipasi itu sendiri menuntut adanya keterbukaan karena tanpa keterbukaan pemerintah tidak mungkin 
mendapatkan peran serta masyarakat dalam kegiatan-kegiatan pemerintahan.

Konsep partisipasi terkait dengan konsep demokrasi, sebagaimana dikemukakan oleh Philipus M. Hadjon (1997) bahwa sekitar tahun 1960-an muncul suatu konsep demokrasi yang disebut demokrasi partisipasi. Dalam konsep ini rakyat mempunyai hak untuk ikut memutuskan dalam proses pengambilan keputusan pemerintahan. Dalam konsep demokrasi, asas keterbukaan atau partisipasi merupakan salah satu syarat minimum, sebagaimana dikemukakan oleh Burkens dalam buku yang berjudul "Beginselen van de democratische rechsstaat" (Philipus M. Hadjon, 1997) bahwa 1). pada dasarnya setiap orang mempunyai hak yang sama dalam pemilihan yang bebas dan rahasia; 2). pada dasarnya setiap orang mempunyai hak untuk dipilih; 3). setiap orang mempunyai hak-hak politik berupa hak atas kebebasan berpendapat dan berkumpul; 4). badan perwakilan rakyat mempengaruhi pengambilan keputusan melalui sarana "(mede) beslissing-recht" (hak untuk ikut memutuskan dan atau melalui wewenang pengawas; 5). asas keterbukaan dalam pengambilan keputusan dan sifat keputusan yang terbuka; 6). dihormatinya hak-hak kaum minoritas.

Asas keterbukaan sebagai salah satu syarat minimum dari demokrasi terungkap pula dalam pendapat Couwenberg dan Sri Soemantri Mertosoewignjo, 1992. Menurutnya, ada lima asas demokratis yang melandasi rechtsstaat, dua diantaranya adalah asas pertanggungjawaban dan asas publik (openbaarheidsbeginsel), yang lainnya adalah: asas hak-hak politik, asas mayoritas, dan asas perwakilan (Philipus M. Hadjon, 1987).

Senada dengan itu, Sri Soemantri M. (1992) mengemukakan bahwa ide demokrasi menjelmakan dirinya dalam lima hal, dua diantaranya adalah: pemerintah harus bersikap terbuka (openbaarheid van bestuur) dan dimungkinkannya rakyat yang berkepentingan menyampaikan keluhannya mengenai tindakan-tindakan penjabat yang dianggap merugikan. Tampak jelas bahwa dalam paham demokrasi terdapat asas keterbukaan, yang berkaitan dengan asas partisipasi masyarakat, sebagaimana pula dikemukakan oleh Franz Magnis-Suseno (1987), bahwa paham demokrasi atau kedaulatan rakyat mengandung makna, pemerintahan negara tetap di bawah kontrol masyarakat. Kontrol ini melalui dua sarana: secara langsung melalui pemilihan para wakil rakyat dan secara tidak langsung melalui keterbukaan (publicity) pengambilan keputusan.

Pertama, pemilihan wakil rakyat berkonsekuensi pada adanya pertanggungjawaban. Karena, jika partai-partai mau terpilih kembali dalam pemilihan berikut, mereka tidak dapat begitu saja mempermainkan kepercayaan para pendukung mereka, sehingga harus mempertanggungjawabkannya. Kedua, keterbukaan pengambilan keputusan merupakan suatu keharusan. Karena pemerintah bertindak demi dan atas nama seluruh masyarakat, maka seluruh masyarakat berhak untuk mengetahui apa yang dilakukannya. Bukan saja berhak mengetahui, juga berhak berpartisipasi dalam proses pengambilan keputusan.

Partisipasi masyarakat itu semakin penting urgensinya dalam proses pengambilan keputusan setelah dikampanyekannya good governance oleh Bank Duniamaupun UNDP. Salah satu karakteristik dari good governance atau tata kelola pemerintahan yang baik atau kepemerintahan yang baik adalah partisipasi.

Selanjutnya UNDP mengartikan partisipasi sebagai karakteristik pelaksanaan good governance adalah keterlibatan masyarakat dalam pembuatan keputusan baik secara langsung maupun tidak langsung melalui lembaga perwakilan yang dapat menyalurkan aspirasinya. Partisipasi tersebut dibangun atas dasar kebebasan bersosialisasi dan berbicara serta berpartisipasi secara konstruktif (Sumarto,2003).

Senada dengan pengertian tersebut, Seidman, Seidman, dan Abeyserkere (2001) memaknai partisipasi sebagai berikut: bahwa pihak pihak yang dipengaruhi oleh suatu keputusan yang ditetapkan the stakeholders (pihak yang mempunyai kepentingan) memiliki kesempatan yang seluas-luasnya untuk memberikan masukan, kritik dan mengambil bagian dalam pembuatan keputusankeputusan pemerintahan. 
Pengertian partisipasi tersebut tidak jauh berbeda dengan pengertian partisipasi politik yang diberikan oleh Huntington dan Nelson (dalam Budiardjo, 1981) bahwa partisipasi politik adalah kegiatan warga negara yang bertindak sebagai pribadi-pribadi, yang dimaksud untuk mempengaruhi pembuatan keputusan oleh pemerintah.

Pengertian partisipasi politik sebagai kegiatan warga negara terlibat dalam proses pengambilan keputusan, dalam kepustakaan kebijakan publik di Belanda disebut inspraak atau partisipasi politik langsung (Demen dan Thomassen, 1983). Ciri terpenting dari partisipasi politik langsung adalah tidak melalui proses perwakilan, melainkan warga negara berhubungan langsung dengan para pengambil keputusan.

Dikaitkan dengan pendapat McClosky, bahwa partisipasi politik adalah kegiatankegiatan sukarela dari warga masyarakat melalui mana mereka mengambil bagian dalam proses pemilihan penguasa, dan secara langsung atau tidak langsung, dalam proses pembentukan kebijakan publik (Budiardjo, 1981). Sehingga jelas, partisipasi politik langsung merupakan salah satu bentuk partisipasi politik dan bentuk lainnya dapat disebut sebagai partisipasi politik tidak langsung.

Dari penjelasan tersebut diatas jelas menunjukan bahwa dalam proses pengambilan keputusan, termasuk pengambilan keputusan dalam bentuk Perda, terdapat hak masyarakat untuk berpartisipasi dalam proses penyusunan Perda, yakni memberi masukan secara lisan atau tertulis dalam persiapan maupun pembahasan rancangan Perda. Menurut Utomo (2003), manfaat partisipasi masyarakat dalam pembuatan kebijakan publik, termasuk dalam pembuatan Perda adalah :

1. Memberikan landasan yang lebih baik untuk pembuatan kebijakan publik.

2. Memastikan adanya implementasi yang lebih efektif karena warga mengetahui dan terlibat dalam pembuatan kebijakan publik.

3. Meningkatkan kepercayaan warga kepada eksekutifdan legislatif.
4. Efisiensi sumber daya, sebab dengan keterlibatan masyarakat dalam pembuatan kebijakan publik dan mengetahui kebijakan publik, maka sumber daya yang digunakan dalam sosialisasi kebijakan publik dapat dihemat. Sesuai dengan ide negara hukum, maka partisipasi masyarakat dalam penyusunan Perda mesti diatur secara jelas dalam suatu aturan hukum tertentu

Menurut Manan (2003) hukum merupakan sumber tertinggi (supremasi hukum) dalam mengatur dan menentukan mekanisme hubungan hukum antara negara dan masyarakat atau antar-anggota masyarakat yang satu dengan yang lainnya. Hukum mempunyai dua pengertian, yakni hukum tertulis dan hukum tidak tertulis. Bapak Pembentuk Negara Indonesia, mengakui adanya hukum tidak tertulis, sebagaimana pernah dituangkan dalam Pembukaan UUD 1945 : "UndangUndang Dasar ialah hukum dasar yang tertulis, sedang di sampingnya Undang-Undang Dasar itu berlaku juga hukum dasar yang tidak tertulis, ialah aturan-aturan dasar yang timbul dan terpelihara dalam praktek penyelenggaraan negara meskipun tidak tertulis" (Majelis Permusyawaratan Rakyat Republik Indonesia, 2004).

Berkenaan dengan negara hukum, Saragih mengemukakan, bahwa legalitas dalam arti hukum dalam segala bentuknya sebagai ciri negara hukum adalah setiap tindakan baik dari pihak penguasa maupun dari pihak rakyat harus dibenarkan secara hukum (Saragih, 1980).

Mengenai asas legalitas, Asshiddiqie (2005) berpendapat, bahwa dalam setiap negara hukum diisyaratkan berlakunya asas legalitas dalam segala bentuknya (due process of law), yaitu bahwa segala tindakan pemerintahan harus didasarkan atas perundangundangan yang sah dan tertulis. Dari pendapat-pendapat tersebut, dapat dikatakan bahwa setiap tindakan penyelenggara negara maupun warga negara harus berdasarkan aturan hukum, baik aturan hukum yang tertulis maupun yang aturan hukum yang tidak tertulis. Yang dimaksud aturan hukum 
tertulis disini adalah peraturan perundangundangan, sedangkan yang dimaksud dengan aturan hukum yang tidak tertulis disini adalah dalam bidang pembentukan peraturan perundang-undangan, yakni asas-asas pembentukan peraturan perundang-undangan yang baik, yang kemudian dituangkan dalam. Dengan demikian, partisipasi masyarakat dalam penyusunan Perda tidak saja cukup diatur dalam peraturan perundang-undangan, namun pengaturannya tersebut haruslah dilakukan secara jelas.

\section{PELAKSANAAN PARTISIPASI PEMBUATAN PERDA}

Beberapa hal yang dapat dilakukan dalam kaitannya dengan pelaksanaan peran serta masyarakat dalam pembentukan perda antara lain: dilakukannya rapat dengar pendapat umum atau rapat-rapat lainnya yang bertujuan menyerap aspirasi masyarakat, dilakukannya kunjungan oleh anggota DPRD untuk mendapat masukan dari masyarakat, ataupun diadakannya seminar-seminar atau kegiatan yang sejenis dalam rangka melakukan pengkajian atau menindak lanjuti berbagai penelitian untuk menyiapkan suatu Rancangan Peraturan Daerah. Akan tetapi dalam pelaksanaannya kadang masih terdapat berbagai penafsiran tentang siapa yang dimaksud dengan istilah masyarakat, ada yang mengartikan setiap orang pada umumnya, setiap orang atau lembaga yang terkait, atau setiap lembaga swadaya masyarakat.

Menurut Indrati (2007) bahwa yang dimaksud dengan masyarakat adalah setiap orang pada umumnya terutama masyarakat yang "rentan" terhadap peraturan tersebut, setiap orang atau lembaga terkait, atau setiap lembaga swadaya masyarakat yang terkait. Mengenai sejauh mana masyarakat tersebut dapat ikut serta dalam pembentukan peraturan perundang-undangan (dalam hal ini UU dan Perda), hal tersebut dapat tergantung pada keadaan dari pembentuk perundangundangan sendiri oleh karena UUD dan berbagai peraturan perundang-undangan telah menetapkan lembaga mana yang dapat membentuk peraturan perundang-undangan tersebut. Apabila suatu Perda telah dapat menampung aspirasi masyarakat luas tentunya peran serta masyarakat tersebut tidak akan terlalu dipaksakan pelaksanaannya. Oleh karena itu diperlukan peningkatan kualitas anggota DPRD maupun seluruh jajaran Pemerintah yang mempunyai tugas membentuk suatu Perda.

\section{KESIMPULAN}

1. Partisipasi masyarakat penting dan strategis. Penting karena pada hakekatnya dialalah pemegang kekuasaan tertinggi dalam negara yang menganut paham demokrasi. Strategis karena dialah yang seharusnya merancang sehingga bukan sekedar menikmati pembangunan semata, akan tetapi juga menata hendak kemana akhirnya pembangunan itu diarahkan.

2. Salah satu bentuk keikutsertaan masyarakat dalam merancang pembangunan adalah dilibatkannya mereka dalam pembuatan peraturan, termasuk peraturan daerah yang disingkat dengan Perda. Dengan demikian segala aktifitas pemerintahan dan pembangunan, masyarakat memperoleh kesempatan mengikuti proses, mulai dari pembuatan peraturan yang akan menjadi penuntun dan pengendali sampai kepada pelaksanaan dan sekaligus evaluasi. Itu berarti masyarakat juga ikut serta bertanggung jawab, apabila dikemudian hari terjadi kesalahan atau penyimpangan pembangunan.

3. Pelaksanaan partisipasi dapat dilakukan dalam berbagai cara misalnya dilakukannya rapat dengar pendapat antara DPRD dengan masyarakat, kunjungan oleh anggota DPRD untuk mendapat masukan dari masyarakat, seminar-seminar atau kegiatan yang sejenis dalam rangka melakukan pengkajian atau menindak lanjuti berbagai penelitian untuk menyiapkan suatu Rancangan Peraturan Daerah, dan sebagainya. 


\section{DAFTAR PUSTAKA}

Ann Seidman, Robert B. Seidman, dan Nalin Abeyserkere, 2001, Penyusunan Rancangan Undang-undang Dalam Perubahan Masyarakat Yang Demokratis, Proyek ELIPS Departemen Kehakiman dan Hak Asasi Manusia Republik Indonesia. Jakarta

Bagir Manan, H., 2003, Teori dan Politik Konstitusi, FH UII Press. Yogyakarta

Daemen, H.H.F.M. dan J.J.A. Thomassen, 1983, "Jarak Antara Warga dan Pemerintah" dalam A.Hoogerwerf, ed., IImu Pemerintahan, terjemahan, Penerbit Erlangga, Jakarta

Fanz Magnis-Suseno, 1987, Etika Politik Prinsip-Prinsip Moral dasar Kenegaraan Modern, PT Gramedia. Jakarta

Gaventa, J. (2001), Towards Participatory Local Governance: Six Propositions for Discussion. Paper presented at the Ford Foundation - LOGO Program Officers' Retreat, Buxted Park, Sussex, England, June 13-15, 2001, carried out in conjunction with the Institute of Development Studies (IDS) Learning Initiative on Local Governance Network (LOGOLink).

Hetifah Sj Sumarto, 2003, Inovasi, Partisipasi dan Good Governance, Yayasan Obor Indonesia. Jakarta
Kusnardi, Moh.dan Bintan R. Saragih, 1980, Susunan Pembagian Kekuasaan Menurut Sistem Undang-Undang Dasar 1945,: Penerbit PT Gramedia. Jakarta

Jimly Asshiddiqie, 2005, Konstitusi \& Konstitusionalisme Indonesia, Penerbit Konstitusi Press.Jakarta

Majelis Permusyawaratan Rakyat Republik Indonesia, ed., 2004, Undang-Undang Dasar Negara Republik Indonesia Tahun 1945, Sekretariat Jenderal MPR RI., Jakarta

Maria Farida Indrati s., 2007, Ilmu Perundangundangan, Kanisius, Yogyakarta.

Miriam Budiardjo, ed., 1981, Partisipasi dan Partai Politik, PT Gramedia, Jakarta

Philipus M. Hadjon, 1987, Perlindungan Hukum Bagi Rakyat di Indonesia, PT Bina Ilmu. Surabaya

Sad Dian Utomo, 2003, "Partisipasi Masyarakat dalam Pembuatan Kebijakan", dalam Indra J. Piliang, Dendi Ramdani, dan Agung Pribadi, Otonomi Daerah: Evaluasi dan Proyeksi, Penerbit Divisi Kajian Demokrasi Lokal Yayasan Harkat Bangsa. Jakarta

Sri Soemantri M., 1992, Bunga Rampai Hukum Tata Negara Indonesia, Alumni. Bandung 